\title{
Nurse Managers Decision Making styles and It's Effect on Staff Nurses' Satisfaction
}

\author{
Mohammed, A., S ; Nassar, M., E; Ghallab , S., A; \& Morsy , S., M . \\ Assistant lecturer Faculty of Nursing Assiut University. \\ Nursing Administration. Faculty of Nursing Alexandria University. \\ Nursing Administration Faculty of Nursing Assiut University.
}

\begin{abstract}
Nurse Manager's main job in contemporary health care organization is to increase degree of employee's participation in decision making and goal setting which in return has greater impact on employee motivation, and satisfaction. This study aimed at determining decision making styles used by Nurse Managers at main Assuit university hospital, and the effect of these styles on Technical diploma nurse' satisfaction. Subject of the study: the sample consisted of 96 Technical diploma nurse and 35 Nurse Managers. Setting: Medical and Surgical units at main Assiut University Hospital. Tools of data collection the data collected using structured questionnaire form. Results: the highest percentage of Nurse Managers were used authoritarian decision making style and the lost percentage were used delegative decision making style. Conclusion: Nurse Managers who were using participative decision making style achieving the highest level of employees' satisfaction. Recommendations Give employees opportunities to participate in goals setting and decisions to increase their commitment toward goal achievement. And further studies should be done including different countries to investigate the effect of cultures on Nurse Managers' decision making styles.
\end{abstract}

Key words: Decision making styles - Satisfaction

\section{Introduction}

Nurse Managers are expected to use knowledge from various disciplines to make decisions pertaining to patients, staff, and the organization, as well as problems in their own personal and professional lives. They also must make decisions in a dynamic situation. Decision-making for nursing defined as a process where by appropriate alternatives are weighted and one ultimately selected. Decisionmaking also is a deliberative, cognitive process consisting of sequential steps that can be analyzed and refined (Sullivan and Decker, 2009).

Kelly-Heidenthal, (2004) stated that, a decision is the last step in the process by which an individual chooses one alternative from several to achieve a desired objective. Moreover decisions are judgments that directly affect a course of action (Pierce and Gardner, 2002). Also Tomey, (2009) defined decision-making as the process of selecting one course of action from a set of feasible alternatives, is a continuing responsibility of nurse leaders and managers who are confronted by a variety of situations. Decision-making is one of the major functions of the Nurse Managers job, so effective nurse manager must use effective style in deal with day living situations (Kelly-Heidenthal, 2004).

Decision - making styles of Nurse Managers are similar to the leadership styles that the managers are likely to use. A manager who leans toward an autocratic style may choose that make decision independent of the input or participation of others, this has been referred to as the "decide and announce" approach, an authoritative style. On the other hand, a manager who uses democratic or participative approach to management involves the appropriate personnel in the decision - making process, however, followers are generally more supportive or consultative and group approaches, Nurse Managers must use different decision making styles in different situation to achieve work satisfaction for her/his subordinates (Yoder-Wise, 2007).

Decisions are made using one of the four styles. The most appropriate style for any given decision depends upon the situation and the readiness of the followers. The basic styles are: Authoritative; very useful when the manager is the only available resources, and have necessary experience and information to reach to a conclusion, consultative; when worker possess some degree of knowledge or expertise the manager still remain the one who makes the final decisions, facilitative; managers and followers work together in a cooperative effort to reach to decision, and delegative decision-making style; is most appropriate when followers with high degree of readiness, experience, and information, the followers own the problems and will make the decisions Clark, 1998 summarized the consultative and facilitative decision-making styles into participative decisionmaking style.

In this respect, Tomey, (2009) said that the appropriate degree of employee participation in the 
decision-making process revolves around the nature of the problem itself, the required level of decision quality, and the importance of having employees' commitment to the decision.

Manager and subordinate relationship must aim to increase employee motivation thus; employee satisfaction will be increased and reached to the peak points (Deckert, et.al. 2004). Morrison et al. (2001) stated that job satisfaction is a multivariate human attitude that has been defined as an effective response of the worker to this job consequences of the workers experience on the job in relation to his /her own values, that is, what he /she want or expect from it. Managers / leaders in today health care organization should inspire others with the vision of what can be accomplished. The decision-making style of the manager/leader is related to the job satisfaction of their subordinates, in many health care organizations, where the head nurses serve as immediate supervisors, the type and quality of decision-making style they used can influence staff nurses, job satisfaction, either positively or negatively (Yoder-

Wise, 2007).

\section{Significance of the study}

As documented by many researchers that many studies were done a bout leadership styles, job satisfaction, job characteristics, absenteeism and turnover, role ambiguity, life satisfaction, goal setting but studies on decision making styles and its effect on job satisfaction not take the same interest.

\section{This study aimed at:}

Determine the decision-making styles used by Nurse Managers at Main Assiut University Hospital, and the effect of these styles on Technical diploma nurse' satisfactions

Research question?

1- What is the decision making style used by Nurse Managers?

2- Do demographic characteristics have a significant effect on Nurse Managers decision making styles?

3- Does participative style achieve high level of Technical diploma nurse ' satisfaction

\section{Subject and Methods:}

Research design: a descriptive correlation design was used to carry out the present study.

Setting; the present study was conducted at all Medical ( 16 departments) and all Surgical departments (20 departments ) it includes (general and specialty departments) at Main Assiut University Hospital.

Subjects: Subjects of the present study included nurse director $(n=1)$, assistant director $(n=2)$, nurse supervisors $(n=2)$, all Nurse Managers working in general and specialty Medical and Surgical departments $(n=30)$ (total 35 Nurse Managers). And representative number of Technical diploma nurse $(n=96)$ from the same selected departments, they systematic randomly selected from their working schedule. They distributed as follow (15 from general Medical department, 27 from Medical specialty departments, 24 from general Surgical departments, and 30 from Surgical specialty departments).

Data Collection Tools. Two data collection tools were used: Tool one decisions - making style questionnaire; developed by Clark, (1998) and updated it in December 2007, it is consisted of 30 statements each ten of them reflects one decision making style responses were measured on 5 points Likert scale ranged from 5 always true to 1 never true. Tool two a structured questionnaire consisted of 2 parts: Part one measure demographic characteristics; it was designed by the investigator to gather data about age, gender, marital status, educational level, job position, years of experience, shelter, and attendance of training courses. Part two questionnaire to measure nurses satisfaction; developed by the researcher to investigate satisfaction of Technical diploma nurse with the decision - making styles used by Nurse Managers based on decision making style questionnaire which developed by clark (1998) it is consisted of 30 statement each ten of them reflect satisfaction about one decision making style, responses were measured on 3 points Likert scale ranged from $\mathbf{3}$ satisfied to $\mathbf{1}$ dissatisfied.

Scoring system decisions - making style questionnaire;

For decision - making style questionnaire; checked items were scored from "5" to " 1 " from always true to never true, respectively. This scoring was reversed in case of negative worded items. The lowest score possible for any stage is 10 (never true) while the highest score possible for any stage 50 (always true). The highest of the three scores indicates what style of decision making you normally use. If your highest score is 40 or more, it is a strong indicator of your normal style. The lowest of the three scores is an indicator of the style you least use. If your lowest score is 20 or less, it is a strong indicator that you normally don't operate out of this mode. If two of the scores are close to the same, you might be going through a transition phase, either personally or at work, except if you score high in both the participative and delegative then you are probably a delegative leader. If there is only a small difference between the three scores, then this indicates that you have no clear perception of the mode you operate out of, or you are a new leader and are trying to feel out the correct style for yourself. 
The scores of each subject in each items were summed up and converted into a percent total score by dividing the gained score by the maximum attainable score, and multiplying by 100 , the mean and standard deviation, were also calculated.

\section{Scoring system nurses satisfaction questionnaire :}

Checked items were scored from "3" to "1" for the questionnaire from satisfied to dissatisfied respectively the score of each subject in each items summed up and converted into a percent total score by dividing the gained score by the maximum attainable score, and multiplying by 100 . There a cut point at $60 \%$, person who attained $60 \%$ and more is considered satisfied meanwhile less than $60 \%$ considered dissatisfied.

Reliability: was ensured by measuring internal consistency using Cronbach's Alpha Coefficients method for all tools included in the present study. Cronbach's Alpha Coefficients results were highly 0.8 and more for all items of the study questionnaires

2- Administrative Design;An official approval to carry out the study was obtained from the responsible persons (hospital director, director of nursing, all departmental heads in which the study is conducted) at main Assuit University Hospital to collect the necessary data for the present study.

3- Operational Design; this design explains the steps of actual implementation of the study including the pilot and the field work

Pilot Study: A pilot study was fulfilled to test the questionnaire clarity, feasibility, understandability. it carried out on ten Technical diploma nurse and five Nurse Managers. Data collected from the pilot study were also reviewed and used in making the necessary modifications prior to the final application of the study tools.

Field Work: after making the necessary modifications, data collection was conducted by the investigator, through personal interview, thus, each participant (Nurse Managers and Technical diploma nurse) at selected department was personally interviewed one at a time, and each interview took about half an hour. The whole duration for data collection took about 3 months from July 2009 until the end of September 2009.

4- Statistical Design; Data entry and analysis were done using SPSS v.g 16.program statistical soft ware package for social sciences. Data were presented using descriptive statistics in the form of frequencies and percentages also mean and standard deviation was calculated. For multiple group comparisons of quantitative data, one -way analysis of variance test (ANOVA) was used, statistical significance was considered at $\mathrm{P}$-value $<0.05$.

\section{Results:}

Table (1) reveals that, more than one third of Nurse Managers $(37.1 \%)$ were less than 35 years old, meanwhile $(2.9 \%)$ of them were 50 years old and more. On the other hand nearly half of Technical diploma nurse $(49.0 \%)$ were less than 35 years old. The majority of Nurse Managers $(85.7 \%)$ and about two thirds of Technical diploma nurse $(66.7 \%)$ were females. Regarding to residence, less than three quarters of Nurse Managers $(74.3 \%)$ and more than half of Technical diploma nurse $(56.2 \%)$ living in urban areas. About (68.6\%) of Nurse Managers has bachelor degree while all Technical diploma nurse $(100 \%)$ have Technical diploma nurse from secondary technical nursing school.

Also the same table reveals that, the vast majority of Nurse Managers and Technical diploma nurse were married $(97.1 \%)$ and $(88.5 \%)$ respectively. As regards years of experience $(34.3 \%)$ of Nurse Managers have from $5-<10$ and 20 years and more while $(31.2 \%)$ of Technical diploma nurse have more than 15 and less than 20 years of experience. The majority of Nurse Managers $(97.1 \%)$ attended training programs. Meanwhile, $(88.5 \%)$ of Technical diploma nurse attended training programs

Table (2) reveals that there is a statistical significant difference between Nurse Managers and Technical diploma nurse' as regarding to participative decision making style only $(\mathrm{P}<0.004)$.

Table (3) depicts that, there is a statistical significant difference as regard to age, level of education ( $\mathrm{P}$ $<0.04)$, years of experience $(\mathrm{P}<0.004)$ and monthly income $(\mathrm{P}<0.003)$ in Nurse Managers used participative decision-making style, meanwhile there is a statistical significant difference regarding to years of experience in Nurse Managers used delegative decision-making style $(\mathrm{P}<0.02)$.

Table (4) explains that, there are a statistical significant differences were found between satisfied and dissatisfied Technical diploma nurse working with Nurse Managers used participative decisionmaking style $(\mathrm{P}<0.000)$ and delegative decisionmaking style $(\mathrm{P}<0.002)$. 
Table 1: Socio-demographic characteristics of the study subjects at Main Assiut University Hospital ( $\mathrm{n}=131)$.

\begin{tabular}{|c|c|c|c|c|}
\hline \multirow[t]{2}{*}{ Socio-demographic characteristics } & \multicolumn{2}{|c|}{$\begin{array}{c}\text { Nurse Managers } \\
(n=35)\end{array}$} & \multicolumn{2}{|c|}{$\begin{array}{c}\text { Technical diploma nurse } \\
(n=96)\end{array}$} \\
\hline & No. & $\%$ & No. & $\%$ \\
\hline \multicolumn{5}{|l|}{ Age: } \\
\hline$<35 \mathrm{y}$ & 13 & 37.1 & 47 & 49.0 \\
\hline $35-<40$ & 7 & 20.0 & 30 & 31.2 \\
\hline $40-<45$ & 7 & 20.0 & 11 & 11.5 \\
\hline $45-<50$ & 7 & 20.0 & 7 & 7.3 \\
\hline 50 and more & 1 & 2.9 & 1 & 1.0 \\
\hline \multicolumn{5}{|l|}{ Gender: } \\
\hline Male & 5 & 14.3 & 32 & 33.3 \\
\hline Female & 30 & 85.7 & 64 & 66.7 \\
\hline \multicolumn{5}{|l|}{ Residence: } \\
\hline Rural & 9 & 25.7 & 42 & 43.8 \\
\hline Urban & 26 & 74.3 & 54 & 56.2 \\
\hline \multicolumn{5}{|l|}{ Education: } \\
\hline Technical diploma nurse & 10 & 28.6 & 96 & 100.0 \\
\hline Bachelor & 24 & 68.6 & 0 & 0.0 \\
\hline Postgraduate education & 1 & 2.9 & 0 & 0.0 \\
\hline
\end{tabular}

Table 1 cont, : Socio-demographic characteristics of the study subjects at Main Assiut University Hospital ( $\mathrm{n}=131)$.

\begin{tabular}{|l|c|c|c|c|}
\hline \multirow{2}{*}{ Socio-demographic characteristics } & \multicolumn{2}{|c|}{$\begin{array}{c}\text { Nurse Managers } \\
(\mathbf{n = 3 5})\end{array}$} & \multicolumn{2}{c|}{$\begin{array}{c}\text { Technical diploma nurse } \\
(\mathbf{n = 9 6})\end{array}$} \\
\cline { 2 - 5 } & No. & $\mathbf{\%}$ & No. & \% \\
\hline Marital status: & & & & \\
\hline Single & 1 & 2.9 & 11 & 11.5 \\
\hline Married & 34 & 97.1 & 85 & 88.5 \\
\hline Years of experience: & & & & \\
\hline$<5$ & 0 & 0.0 & 11 & 11.5 \\
\hline $5-<10$ & 12 & 34.3 & 15 & 15.6 \\
\hline $10-<15$ & 4 & 11.4 & 21 & 21.9 \\
\hline $15-<20$ & 7 & 20.0 & 30 & 31.2 \\
\hline 20 and more & 12 & 34.3 & 19 & 19.8 \\
\hline Training programs: & & & & \\
\hline Yes & 34 & 97.1 & 85 & 88.5 \\
\hline No & 1 & 2.9 & 11 & 11.5 \\
\hline
\end{tabular}

Table2: Decision making styles used by Nurse Managers as perceived by themselves and by Technical diploma nurse at Main Assiut University Hospital ( $\mathrm{n}=131)$.

\begin{tabular}{|l|l|l|l|l|l|l|l|}
\hline \multirow{2}{*}{$\begin{array}{l}\text { Decisions making } \\
\text { styles }\end{array}$} & \multicolumn{3}{|l|}{$\begin{array}{l}\text { Nurse Managers } \\
(\mathbf{n = 3 5})\end{array}$} & $\begin{array}{l}\text { Technical diploma nurse } \\
(\mathbf{n = 9 6 )}\end{array}$ & \multirow{2}{*}{ P-value } \\
\cline { 2 - 9 } & No. & $\%$ & Mean \pm SD & No. & $\%$ & Mean \pm SD & \\
\hline Authoritarian & 25 & 71.4 & $33.97 \pm 5.68$ & 67 & 69.8 & $34.48 \pm 6.43$ & 0.675 \\
\hline Participative & 26 & 74.3 & $53.37 \pm 8.02$ & 42 & 43.8 & $29.66 \pm 9.85$ & $0.004^{*}$ \\
\hline Delegative & 13 & 37.1 & $26.28 \pm 9.47$ & 25 & 26.0 & $22.98 \pm 9.81$ & 0.089 \\
\hline
\end{tabular}

(*) Statistically significant at $\mathrm{P}<0.05$ 
Table 3: The relationship between Socio-demographic characteristics and Nurse Managers decision-making styles at Main Assiut University Hospital $(\mathrm{n}=35)$.

\begin{tabular}{|c|c|c|c|c|c|}
\hline \multirow{2}{*}{$\begin{array}{l}\text { Socio-demographic } \\
\text { characteristics }\end{array}$} & \multirow{2}{*}{ No. } & \multirow{2}{*}{$\%$} & Authoritarian & Participative & Delegative \\
\hline & & & Mean \pm SD & Mean \pm SD & Mean \pm SD \\
\hline \multicolumn{6}{|l|}{$\overline{\text { Age: (years) }}$} \\
\hline$<40$ & 20 & 57.15 & $32.95 \pm 5.68$ & $33.00 \pm 8.15$ & $24 \pm 9.33$ \\
\hline$\geq 40$ & 15 & 42.85 & $35.33 \pm 5.59$ & $38.53 \pm 6.88$ & $29.33 \pm 9.08$ \\
\hline \multicolumn{3}{|l|}{ P-value } & 0.220 & $0.040^{*}$ & 0.100 \\
\hline \multicolumn{6}{|l|}{ Gender: } \\
\hline Male & 5 & 14.3 & $32.4 \pm 7.26$ & $39 \pm 10.79$ & $29 \pm 11.24$ \\
\hline Female & 30 & 85.7 & $34.23 \pm 5.48$ & $34.76 \pm 7.53$ & $25.83 \pm 9.29$ \\
\hline \multicolumn{3}{|l|}{ P-value } & 0.513 & 0.281 & 0.497 \\
\hline \multicolumn{6}{|l|}{ Residence: } \\
\hline Rural & 9 & 25.7 & $32.66 \pm 6.28$ & $36.22 \pm 8.81$ & $29.11 \pm 10.95$ \\
\hline Urban & 26 & 74.3 & $34.42 \pm 5.52$ & $35.08 \pm 7.89$ & $25.30 \pm 8.93$ \\
\hline \multicolumn{3}{|l|}{ P-value } & 0.433 & 0.718 & 0.307 \\
\hline \multicolumn{6}{|l|}{ Education: } \\
\hline Technical diploma nurse & 10 & 28.6 & $34.10 \pm 7.15$ & $39.60 \pm 8.39$ & $28.90 \pm 10.54$ \\
\hline Bachelor \& postgraduate & 25 & 71.4 & $33.92 \pm 5.15$ & $33.68 \pm 7.37$ & $25.24 \pm 9.03$ \\
\hline \multicolumn{3}{|l|}{ P-value } & 0.934 & $0.040^{*}$ & 0.309 \\
\hline \multicolumn{6}{|l|}{ Years of experience: } \\
\hline$<15$ & 16 & 45.7 & $33.93 \pm 5.47$ & $31.25 \pm 6.70$ & $22.37 \pm 8.01$ \\
\hline$\geq 15$ & 19 & 54.3 & $34 \pm 6.00$ & $38.84 \pm 7.50$ & $29.57 \pm 9.54$ \\
\hline \multicolumn{3}{|l|}{ P-value } & 0.975 & $\mathbf{0 . 0 0 4}^{*}$ & $0.020^{*}$ \\
\hline
\end{tabular}

(*) Statistically significant at $\mathrm{P}<0.05$

Table 4: Decision-making styles of Nurse Managers and it's effect on technical diploma nurse' satisfactions at Main Assiut University Hospital (n=96).

\begin{tabular}{|l|c|c|c|c|c|c|c|}
\hline \multirow{2}{*}{ Decision-making styles } & \multicolumn{2}{|c|}{ Satisfied } & \multicolumn{2}{c|}{ Dissatisfied } & \multicolumn{2}{c|}{ Total } & \multirow{2}{*}{ P-value } \\
\cline { 2 - 8 } & No. & $\%$ & No. & \% & No. & \% & \\
\hline Authoritarian style & & & & & & & \multirow{2}{*}{$\mathbf{1 . 0 5 3}$} \\
\hline Authoritarian & 37 & 55.2 & 30 & 44.8 & 67 & 69.8 & \\
\hline Participative style & & & & & & & \multirow{2}{*}{$\mathbf{0 0 0 *}$} \\
\hline Participative & 39 & 92.9 & 3 & 7.1 & 42 & 43.8 & \multirow{2}{*}{$\mathbf{0 . 0 0 2 *}$} \\
\hline Delegative style & & & & & & & \\
\hline Delegative & 21 & 84.0 & 4 & 16.0 & 25 & 26.0 & \\
\hline
\end{tabular}

(*) Statistically significant at $\mathrm{P}<0.05$ 


\section{Discussion:}

Making decisions in the twenty-first century required reflective thought, interdisciplinary focus, global perspectives, use of technology, and comfort with ambiguity (Hammond, Keeney, \& Raiffa, 2008). Nurse Managers face challenges every day when supervising their employees. A choice for one person may not be appropriate for another (Tomey, 2009).

Job satisfactions in the present study not mean general job satisfaction which refers to satisfaction of employees regarding to (income, supervision, work condition, organizational policies .....etc) but means satisfactions of employee about the style used by Nurse Managers when making decisions (Deckert, et.al. 2004).

In this study 96 Technical diploma nurse and 35 Nurse Managers belonging to Main Assiut University Hospital were surveyed with the aims of determine the decision making styles used by Nurse Managers at Main Assiut University Hospital and study the effect of these styles on Technical diploma nurse' satisfactions.

The present study findings showed that, there were no statistical significant differences between Nurse Managers and Technical diploma nurse perception of decision making styles used by Nurse Managers as regard authoritarian, and delegative decision making styles. While there were a statistical significant difference regarding to participative decision making style (table 2), these findings were compatible with Stewart (1989) in studying the effect of decision making styles on openness and satisfaction. On the other hand these findings are in inconsistent with Mohammed (1999) as he found that, there was agreement between managers opinions and subordinates opinions regarding to participative decision making style as well as other styles.

In the same line findings of the present study showed that, there was a slight agreement between Nurse Managers and Technical diploma nurse' opinions as regards authoritarian, and delegative decision making styles. This could be interpreted as it reflects the real decision making styles used by Nurse Managers when making decisions, however the difference in their opinions regarding to participative decision making style does not reflect the real situation. In addition, the decision making styles used by Nurse Managers, and analysis of Technical diploma nurse' opinions showed that, the highest percentage of them were used authoritarian decision making style followed by participative decision making style and lastly delegative decision making style (table 2).

This finding goes in the same line with studies done by Jones, (1982) and Tricamol, (1984) who were reported that, managers tend to be more autocratic in their decision making styles. On the contrary a study done by Mann, (1982) who noted that, analytical directive decision making style is considered the highest style practiced by managers. Also Leon, (1989); Keller, (1995); and Carlson, (1995) were concluded that participative decision making style represents the highest style used by managers. Moreover, studies done by Muna, (1979) Ali \& Swiercz, (1985); Stewart, (1989); Cobelli \& Muth, (1990) found that, consultative decision making styles were the highest style used by managers.

The results of the present study revealed that, there were statistical significant relation among age, education, and years of experience with Nurse Managers using participative decision making styles. Meanwhile there were statistical significant relation regarding to delegative decision making styles and years of experience. At the same time there were no statistical significant relations among gender, residence and Nurse Managers' decision making styles. From these results, it could be concluded that, Nurse Managers become more participative when age, and years of experience meanwhile secondary technical Nurse Managers (Technical diploma nurse ) are participative than bachelor degree Nurse Managers (table 3).

This finding was consistent with Mohammed, (1999) who found that, there were a statistical significant differences regarding to decision making styles and age, years of experience, and monthly income, while disagreed with the present study result regards to level of education as he found that, there was no statistical significant relation between level of education and decision making styles. A study done by Chusmir, et al (1989) who disagreed with the present study findings as they found that, there was no impact of age on decision making styles.

Regarding to gender Carmody (1987) goes in the same line with the present study results, who referred that there was no impact of gender on decision making styles. Meanwhile the study findings were inconsistent with Tofany, (1988) who found that, there were statistical significant differences between decision making styles and gender.

This might be attributed to that, Technical diploma nurse who have Technical diploma nurse degree from secondary technical nursing school and have promoted to administrative positions based on their years of experience in the current department mostly were using participative decision making style as they were sharing and involving their staff members (Technical diploma nurse) in decision making more than bachelor degree Nurse Managers were doing. This leads to that Nurse Managers who have Technical diploma nurse degree may feel more safe and secure when they delegating responsibilities and 
work burden as solving current work problems among the team and they increase degree of participation to avoid taking the risks of doing mistakes and, intentionally to avoid others blame in the future.

From analysis of the present study it was revealed that, more than half of Technical diploma nurse working with Nurse Managers using authoritarian decision making style were satisfied with it. Meanwhile, the majority of Technical diploma nurse working with Nurse Managers using participative and delegative decision making styles were satisfied too table (4). Also from study finding, it's observable that Technical diploma nurse' level of satisfaction decreased markedly with authoritarian decision making style while, increased in delegative decision making style and reach to the peak point with participative decision making style.

This study findings were in agreement with the study done by Ali \& Swiercz, (1985) as they studied decision making styles in different six Arabic countries, concluded that, participative decision making style was the highest style in achieving employees satisfaction and it's more common among managers with low level of education as higher educated managers tend to use autocratic style of decision making. Also Stewart (1989); Ali (1993); Ali et al. (1995) and Mohammed (1999) expressed the effect of decision making style on staff satisfaction, and they found that participative decision making style achieves high level of employees' satisfactions than authoritarian decision making style.

High level of employee's satisfaction which achieved by using both participative and delegative decision making styles this may due to participation of Technical diploma nurse in decision making which gave them a sense of commitment.

\section{Recommendation(s):}

Nurse Managers must achieve high level of employees' satisfaction by giving employees opportunities to participate in goals setting to increase their commitment toward goal achievement and supporting decision-making styles that take into account employees' participation and achieve positive result on employee satisfaction

\section{References}

1. Ali, J. (1993): Decision-Making Styles Individualism, and Attitudes Toward Risk of Arab Executives "Int. Studies of Mgt \& Org.19 (2).
2. Ali, J. and Swiercz, B. (1985): Managerial Decision-Making Styles and Work Satisfaction in Saudi Arabia' .Management Decision 23, (1) P.p 12-19.

3. Ali, J.; Farid, A.; and Muna, O. (1995): Expatriates and Host Country Nationals; Management Values and Decision-Making Styles " Leadership and Organizational Development Journal 16 (6).

4. Carlson R. (1995): " Chief Executive Officers in A School District Community College District, and A Profit Organization: A Comparative Study in Decision-Making Processes and Styles. Unpublished Dissertation for the E.D.D. Degree University of California U.S.A.

5. Carmody, S. (1987): Educational Administrative Decision-Making Style: Men Women, Administrators and Trainees, Clark Country School District. Unpublished Dissertation for the E.D.D. Degree, Brigham Young University U.S.A.

6. Chusmir, H. ; Kobery, L. ; and Mills, R (1989): Male- Female Difference in the Association of Managerial Styles and Personal Values. The Journal of Social Psychology 129 (1) February P.p 65-78

7. Clark, D.(1998): Originating a movement. Cicely Saunders and the development of St. christopher's Hospice, 1957-1967. Mortality, 3 (1), 43-63 from Http://www.nwlink.com/donclark/leader/surv style.html.

8. Cobelli, J. and Muth, R. (1990): "Administrative Decision-Making Styles in Higher Education" Paper Presented at the Annual Meeting of the American Education Research Association (Boston, MA., April 16-20)

9. Deckert, B.; Oldenburg, C. ; Pattison, K. ; and Swartz, S. (2004): Clinical Ladder. Nursing Management 15(3):54-62.

10. Hammond, J. Keeney, R. \& Raiffa, H. (2008): The Hidden Traps in Decision Making. Harvard Business Review 76(5):47-58.

11. Jones, A. (1982): An Analysis of Perception about the Processes of Executive DecisionMaking in Four Complex Organizations" Unpublished Dissertation for the E.E.D. Degree. Temple University U . S. A.

12. Keller, R.(1995):A Longitudinal Study of Leaders Reward Behavior Subordinates Expectancies Decision-Making styles and Satisfaction Personnel Psychology Vol 3 (1).

13. Kelly- Heidenthal, P. (2004): Essentials of Nursing Leadership and Management, DecisionMaking and Critical Thinking, Delmar Learning, 
A division of Thomson Learning, Inc. Thomson, Chapter 11 P.p. 222-240.

14. Leon, O (1989): "Leadership Styles of DecisionMaking in the Academic Department," Unpublished Dissertation for the M.A. Degree, University of Louisville, U.S.A.

15. Mann, R. (1982): " Relationships between the Decision-Making Styles of Corporate Planners and other Planning Executives: their Environmental Focus. Organizational Structure and Task Requirements" Unpublished Dissertation for the Ph. D. Degree, University of Southern California, U.S.A.

16. Marquis, B.\& Huston, C.(2009): Leadership Roles and Management Functions in Nursing Theory and Applications, Decision Making, Problem Solving, and Critical Thinking Requisites for Successful Leadership and Management; $6^{\text {th }}$ ed. Philadelphia, Lippincott unit 1 P.p 1-31\& 602\&575.

17. Mohammed, R. (1999): the Impact of DecisionMaking styles on job performance thesis submitted for the attainment of doctor of Philosophy in Business Administration P.p 164191

18. Morrison, R.; Jones, L. and Fuller, B. (2001): The Relation between Leadership Styles and, Empowerment on Job Satisfaction of Nurses JONA, 27 (5):29

19. Muna, A. (1979): The Arab Executives, University of London London Business School fundamental of management $2^{\text {nd }}$ ed, New P.p. 4361 Jersey: Prentice-Hall International, Inc.

20. Pierce, J.\& Gardner, D. (2002): Management And Organizational Behavior An Integrated Perspective, Organizational Decision-Making Chapter9; Job Satisfaction Chapter 6 P.P 192200; Job Performance Chapter 8 P.P 260- 271 and by South-Western, A Division of Thomson Learning.

21. Stewart, L. (1989): The Effect of DecisionMaking Styles on Openness and Satisfaction within Japanese's Organization "communication monographs Vol.35, (3) Sept.

22. Sullivan, E\& Decker, P.(2009): Effective Leadership and Management In Nursing, $7^{\text {th }}$ ed. P.p 104-119 by Pearson Education, Inc. Upper. Saddle River, New Jersey Pearson Prentice Hall.

23. Tofany, M. (1988): "The Relationship between Sex, Sex Role and Decision Making", Unpublished Dissertation for the E.D.D. Degree, the University of Rochester, and U.S.A.

24. Tomey, M. (2009): Guide to Nursing Management and Leadership, $8^{\text {th }}$ ed. DecisionMaking Process and Tools Chapter3 Mosby, Inc., an Affiliate of Elsevier, Inc.
25. Tricamo, T. (1984): "Department Decision Making, the Relationship of Prestige and Paradigm Development to Control and Consensus", Unpublished Dissertation for the Ph.D. Degree Stanford University, U.S.A.

26. Yoder-Wise, P. (2007): leading and managing in nursing $4^{\text {th }}$ ed part I chapter 5 making decisions and solving problems P.p. 94-96 Mosby Elsevier. 